\title{
Life Histories Center Performance as Response to Text
}

\author{
Susan Browne and Marjorie Madden
}

\begin{abstract}
Based in anthropology (Cole \& Knowles, 2001), life history inquiry into literature emphasizes deep understandings of literary characters that are expressed through dramatic performance. For teachers or teacher-educators, life histories offer a powerful teaching strategy. Life histories support locating readers in a particular pattern or "grammar" of events, situations, and goals while also revealing the subjective worlds of characters who are involved in such events. In an undergraduate Honors Literacies course, life histories performances in response to the young adult novel, The Skin I'm In (Flake, 1998), enabled examinations of the complex interaction of characters, their lives, and particular contexts.

"It is in its potential to make 'imaginative contact' with readers that much of the power of life history lies. Life history can move people." (Sikes, 2006, p. 8)

Drawing on the field of anthropology and the work of Cole and Knowles (2001), life history inquiry into literature is about gaining insights into the broader human condition by coming to know and understand the experiences of literary characters through performance. It is about understanding a situation, profession, condition, or institution through coming to know how characters walk, talk, and work within the particular worlds the author creates. A life history is a dramatic performance that is created based on deep inquiry into a literary character. In an undergraduate Honors Literacies course, life histories in response to the young adult novel, The Skin I'm In (Flake, 1998), enabled examinations of the complex interaction of characters, their lives, and particular contexts.

We use the term "life histories" to describe a space in which readers can make sense of the world through multiple modes of engagement with provocative texts. Life histories are a collaborative tool that helps readers understand and appreciate diverse human experiences as well as gain new and critical understandings about themselves and their world. Readers engage in creating, writing, and ultimately performing life histories. These life histories are written collaboratively and final dramatic performances are created live or as videos posted on websites such as YouTube. For teachers or teacher-educators, life histories inquiry emerges as a powerful teaching strategy that allows for inquiry into literary characters and the critical issues that surround them.
\end{abstract}

\section{Life Histories as a Research Methodology}

Although there is no research on using life histories as a literacy strategy for enhancing comprehension and character understanding, there is much research on the importance of life history as a research methodology. Two recognized ways that adults make meaning and better understand the world are through narrative and dialogue (Bruffee, 1999; Rossiter, 1999). As people understand their lives in terms 
of stories, meaning making takes a narrative form (Bruner, 1990), whereas shared meaning and authenticity are at the heart of dialogue (Bakhtin, 1986). People relate their own life narratives through their memories and interpretive meanings. Anthropologists James Peacock and Dorothy Holland (1993) have proposed using the term "life-focused" to refer to the history that primarily addresses the factual events and subjective experiences of the subject. Further, how the subject tells the story reflects the meaning the subject has made of his or her life experiences; life stories are also always contextual. In our work with life histories, we seek to show ways to engage students in reading books and to help them to see the power of reading texts, fiction, and expository. The focus on performance derives from perspectives such as Bruner's (1990), that recognizes the imaginative use of narrative to engage readers in the exploration of human possibilities by situating them simultaneously in a "dual landscape" of both action and consciousness. Life histories performances support locating readers in a particular pattern or "grammar" of events, situations, and goals while also revealing the subjective worlds of characters who are involved in such events.

\section{Literature Selection and the Making of Life Histories}

We characterize provocative texts as literature that uses themes, contexts, and characters to broaden or change the way readers look at themselves and the world. This literature is quality by nature and lends itself to the critical inquiry that takes place during the life histories process. Young adult literature that can be defined as multicultural and/or critical as seen in Table 1 below has been the basis for our experiences creating life histories with students at the university, middle school, and elementary level.

Table 1: Characteristics of Multicultural Literature and Critical Text

\begin{tabular}{|c|c|}
\hline MULTICULTURAL LITERATURE & CRITICAL TEXT \\
\hline $\begin{array}{l}\text { Multicultural literature is "literature about racial or ethnic } \\
\text { groups that are culturally and socially different from the white } \\
\text { Anglo-Saxon majority in the United States, whose largely } \\
\text { middle-class values and customs are most represented in } \\
\text { American literature" (Norton \& Norton, 2003, p. 457). } \\
\text { - Multicultural literature is rich in cultural detail. } \\
\text { - Multicultural literature uses authentic dialogue, and } \\
\text { presents cultural issues in enough depth that the } \\
\text { readers can think and talk about them. } \\
\text { The inclusion of cultural groups is purposeful and } \\
\text { never simply fulfills a quota (Yokata, 1993). } \\
\text { Multicultural literature accurately reflects a group's } \\
\text { culture, language, history, and values without } \\
\text { perpetuating stereotypes. }\end{array}$ & $\begin{array}{l}\text { Critical literacy is concerned with what bell hooks } \\
\text { (1993) calls the privileged act of naming. A lived } \\
\text { experience linked to processes of self-recovery and } \\
\text { naming represents a mobilization and a means for } \\
\text { shifting power. } \\
\text { - The literature does not make difference } \\
\text { invisible, but rather explores what } \\
\text { differences make a difference. } \\
\text { - The literature enriches our understanding } \\
\text { of history and life by giving voice to those } \\
\text { who traditionally have been silenced or } \\
\text { marginalized. } \\
\text { - The literature shows how people can begin } \\
\text { to take action on important social issues. } \\
\text { The literature explores dominant systems of } \\
\text { meaning that operate in our society to } \\
\text { position people and groups of people. } \\
\text { The literature does not provide "happily } \\
\text { ever after" endings for complex social } \\
\text { problems (Leland, Harste, Ociepka, } \\
\text { Lewison, \& Vasquez, 1999). }\end{array}$ \\
\hline
\end{tabular}




\section{Life Histories as Creative Process}

Louise Rosenblatt (1986) describes (1) the text as stimulus, activating the reader's experience with literature and life and (2) the text as a blueprint for ordering, rejecting, and sketching what is evoked from the reader. Life histories are very much grounded in transactional theories of reading. The term "transaction" emphasizes that meaning is being built through the back-and-forth relationship between reader and text while reading. When reading from the aesthetic stance, attention is on what the reader lives through while in relationship with the text. Life histories involve responding to text through collaborative writing and performances. However, life histories are very different from response activities such as reader's theater and tableau. In life histories, students engage in inquiry and construct ideas by going back into the text to work on representing aspects of the text for themselves and others (see Table 2 below). Linde (1993) argues that life histories also show the complex interactions between characters and cultural contexts.

Table 2: Crafting Life Histories

\section{Crafting Life Histories \\ Character Analysis}

1. Readers identify the main characters in the text and identify their significance.

2. Readers work in small groups and select a major character to work on.

\section{Intensive Reading}

3. Readers revisit the text and begin note taking. They mark the text or use sticky notes to identify directly from the text what they know and understand about their character.

\section{Interpretative Writing}

4. Readers use their notes and text markings to engage in collaborative script writing that gives voice to their character. One group member serves as the scribe.

\section{Performance}

5. Readers perform the life histories. The performance can be given by one or more group members in the form of a monologue, dialogue, or poem. Performances are digitally recorded.

\section{Character Analysis}

Life histories feature culturally defined landmark events in a life (i.e., birth, death, discrimination), make some sort of evaluative point about how characters want to be seen by their readers, and do not stand alone but are linked in a web to other stories (Linde, 1993).

Life histories begin with literature that offers richly nuanced character portrayals. The characters that are integral to the narrative are identified and the importance of each of the identified characters in pushing the narrative forward is agreed upon. In pairs or small groups, students select a character that they will give voice to in writing. The groups go back into the text and read intensively about their character. Reading and rereading is central to crafting life histories. Life histories require students to revisit the text for note taking to enable deeper thinking and engagement. 
At this level, reading takes on reflective characteristics as readers engage in deliberate interpretations of messages in the text. During rereading, students mark the text or use sticky notes to identify what they know and understand about their character. Students engage in mindful and deliberate interpretation of their characters using literal and inferential textual information. In this process of intensive reading, groups extended themselves deeply into the literature. The emphasis is on the lived experience: connecting in personal ways with the story world and actually living in the author's invented world.

\section{Interpretation of Characters-Writing}

This step requires readers to go back into the text again. Using notes and text markings, students engage in collaborative script writing that gives voice to their character. This layered process takes place over time in which groups synthesize the information they gather while one group member serves as the scribe for multiple drafts. The writing is crafted to have meaning for someone who has not read the book. Decisions are made to determine how the completed writing will take shape. The possibilities include a character monologue, dialogue, poem, or "Talk Show" interview.

\section{The Performance}

This final step is where the work is amplified through performance. Here the value of performance in making meaning of texts is demonstrated (Edmiston \& Wilhelm, 1998). The performances can be live and should always be digitally recorded. Performance can be shared among classmates, with other classes, the entire school, and/or outside guests. Digitally recorded performances can be uploaded to websites for further amplification.

\section{The Skin I'm In: Performative Life Histories}

The Skin I'm In (Flake, 1998) is a young adult novel that tells the story of Maleeka, a seventh grader who finds refuge in her journal when the sting of colorism and peer pressure engulf her. Her dark skin color and limited wardrobe cause her to be targeted by a middle school bully. The book was used in an undergraduate Honors Literacies course in a northeastern university to generate discussions around difference in a class of sophomores and juniors where all but one student was white. The text was selected because of its rich potential in fostering cross-cultural empathy. Flake's novel embodies themes such as identity, class, colorism, and bullying. As the story and characters unfolded in the life histories process, themes emerged around identity that can be characterized as struggling with identity, having identity disrupted, and seeking one's best self. Yet, it is through script writing and final performances that these themes come to life, bringing students to a deeper understanding and empathy for the human qualities depicted in Flake's characters.

Jared, a white male in our class, asked if he could write a poem to be delivered as spoken word for his life histories performance as the character Caleb, a seventh grader who admires Maleeka from afar. In excerpts from his poem, Jared's interpretation of Caleb is somber; he is written and performed as an outsider very much like Maleeka. 


\section{Struggling With Identity}

And here I am,

Caleb, poet, scholar

But in the school where defiance ruled king

Why even bother?

Instead I laid low

Praying the teachers not call my name

Though they're answers I knew,

Reciting them would lead to shame.

Trapped more by my head

Than the schools four white walls

I wrote in a book that I kept in a bag

Buried deep in the locker somewhere far in the halls

And on top of their pages was no author to brag.

It seemed someone heard each day I prayed

Because in walked my queen Maleeka,

A girl like me that didn't hide from appreciating words and art

And even though she didn't know

What I have been doing fine for years Maleeka couldn't shake.

This poem excerpt provides a window into Caleb's understanding of self; and later, Caleb's poem captures pieces of Maleeka that help readers shape her identity. Beyond demonstrating an understanding of the character, Jared's poem captures Caleb's deep emotion. The spoken word script that Jared crafted is situated in the world of middle school, difficult choices, wanting to fit in, and the fear of what happens when one does not.

A second script portrays vividly the relationship between Char and Maleeka, yet simultaneously provides a window into Charlese or Char. Maleeka knows she is a bully, yet she allows a relationship to grow between them-one in which Maleeka does Char's homework and, in turn, Char provides Maleeka with a more fashionable wardrobe. Nikki and Thomas extended the story in their life histories that takes Char to therapy. In the dialogue between Char and the doctor, Char maintains her tough persona and quips that she has never explained herself to anyone, yet she goes on to explain herself in detail.

Doctor: Whenever you would like to begin... we have forty-five minutes left... unless you want to just sit there and stare at me ...

Char: You asked me why I did what I did in Mrs. Saunders classroom and I not saying I did... I ain't never explained myself to nobody so listen good and clear now cause there ain't gonna be no repeats. My name is Charlise Jones, people call me Char, and I got a fun fact for you Mr. Psychiatrist I got all those punks fooled back at that dump they call school..." Oh Chars a bully she's so mean, that Char is crazy like she is"... never in my face of course them idiots wouldn't dare. I'd knock them sideways till their teeth was gone... they wouldn't.

A third script focusing on the teacher, Miss Saunders, demonstrates ways that the characters struggle with identity. Miss Saunders, a 40-year-old successful businesswoman, becomes disillusioned and takes a year to teach English at an inner-city school. Elise and Kylie's monologue captures Miss Saunders' struggle with identity: 
At the age of 40 I was a very successful businesswoman. Through the advertising agency I worked with I got to see the world. I was always ahead, wore all the latest fashions and had money to burn. My life was figured out and yet there was something missing. I was always competing, and for what this feeling of incomplete? I needed more so when the agency offered the opportunity to take a year to teach at an inner-city school it was like destiny was slapping me in the face. Maybe giving back could fill this void, maybe it was exactly what I needed. I accepted the offer, ready to give back and determined that McClenton Middle School was going to be my new beginning.

\section{Disrupting}

A significant moment in the text develops when Caleb falls victim to his peers and abandons an opportunity to show his feelings for Maleeka in front of others. Jared's poem continues and indicates that Caleb immediately realized that this was not the right choice.

Our classmates soon drove her to tears and I knew that I was next to break.

On a field trip all aboard the crowd screamed at me to leave my queen

And rather than fall to the hoard

I left her side and joined their scene

If I had known the guilt to follow I would never have had the thought.

The whole next year my heart felt hollow for abandoning what my parents taught.

I tried to do right with my queen for falling for the tricks of traitor

But I knew that ___ queen deserves something, someone much greater.

The words I used to win her heart now held nothing to her broken trust.

A second example of disrupting identity emerges in the Char script. Trying to go beneath her tough exterior, the conversation with the therapist continues:

Doctor: Have you Char... been surviving?

Char: They think that I am the monster well they haven't begun to know JuJu, her voice screaming is one of the memories I have before leaving that stupid town... "I take care of you, I let you wear my Prada, I let you stay up and help at my fabulous parties, and now you think you are some queen and make me look bad you worthless ungrateful child, take off my watch you parasite you have been a thorn in my side for too long"... well I kept that watch dearest sister and a few of her gowns also. Why should I be the only one that gets pushed around like a dog in my own house? Why shouldn't everybody else know how it feels like to feel like scum to the people they see every day, every single day? Maleeka asked for it. I never talked to her until she begged to do my homework so she could have the protection of my name. I learned to defend myself on my own so that no one would dare cross me, why couldn't she do the same? I ignored her but she wouldn't leave me alone. Why not doc? Why? Me, Raiz*, and Reina were fine before she came along, black as coal and dressed in rags. I made her. Mrs. Saunders liked her, and Caleb liked her, who liked me? 
Elise and Kylie indicate in their monologue the ways in which Miss Saunders' identity is continually disrupted.

I knew that first day was going to be the scariest. Not only was I going to be the new inexperienced teacher, but I also had a discolored birthmark on my face that made me more than standout. Most adults had difficulty responding to my face with tact or grace, let alone kids. I've had to deal with how people responded to my face all my life. People have been less than kind to me because of my birthmark, and I'Il admit it took me a long time to love and accept myself.

Oh I knew that first day was going to be rough, I however didn't anticipate getting lost. Thank goodness I wore my Prada, and name brands, they'd help make a good first impression. I had been wandering around the school for quite some time in search of the main office when I finally decided to stop and ask someone to point it out to me. I approached a girl and asked her where the main office was, at first she didn't answer; her eyes darted to my birthmark and then away. She looked down and answered.

\section{Seeking One's Best Self}

Finally, the life histories scripts pointed to the ways characters might find their best selves. Even though Maleeka was the main character in the text, students elected to address her through the voices of secondary characters and crafted compelling life histories to do so. Maleeka evolves to recognize her own worth. On the brink of acknowledging a need to become better, Char does not quite get there. That is not true for Caleb and Miss Saunders who both experience significant turning points as expressed in the scripts:

My father's words rang in my head And filled me with a sense of might I stared in the bathroom mirror and recited you have to take a stand when things aren't right. My lose apologies of the past I knew now did not matter, Right now it was time to act, the strife I built would now soon shatter.

One day too late though I would learn the next morning

Char and her mind games had conquered my queen.

I had looked at Maleeka who had ignored my warning and finally felt the betrayal she had seen. Her face told the story of dishonest and tensions and shame for succumbing what I had warned I knew that I had finally regained her attention and could finally patch the fibers that were torn. It took all that she had but Maleeka confessed that her actions resulted from being driven too far. I looked at my queen and for the first time felt blessed for finding the brightest of stars.

Elise and Kylie conclude their monologue with Miss Saunders coming to powerful realizations that will enable her to appreciate the person she sees in the mirror.

Maleeka frustrated me the most, and at first I didn't know why. Here was a beautiful, intelligent girl, with all the potential in the world, and yet she denied her worth. She hid her intelligence, did what she was told by equals and continued to believe what everyone else said about her. She'd let Char boss her around just so she could wear her clothes, didn't she know that clothes didn't make you who you were, but instead what was on the inside did? To feel as though she belonged, she let others rule her life and she put up a front that depicted her as an individual who didn't care about school. Didn't she know that applying herself would take her beyond the 
very people who wanted to hold her down, even when one of those people was her? Didn't she know she had to quit the façade and just accept her for her?

Oh this girl she frustrated me, but why!? Oh my, it wasn't just her I was frustrated with. I was frustrated with me too. How couldn't I see it before? All this time I thought I had overcome my birthmark, but I hadn't. Boy was I good at talking the talk. I hadn't accepted myself, I simply compensated for what I consider miss comings. My designer clothes or need for perfection weren't signs of acceptance but instead signs of unsureness, denial of being self-conscious, and the feeling of not belonging. All along I thought I was here to help these young students view themselves in an accurate light, never did I dream that they'd bring me to the realization that I too had to cut myself some slack and accept the person staring back at me in the mirror. I set out wanting to help Maleeka, in the end she helped me more than I thought possible. I now understand that there's no use in hiding one's face, imperfection is beauty, simply accept and embrace it.

\section{Life Histories Performances Move Beyond Reading}

Nieto (1992), in arguing for the importance of multicultural literature so that all readers may see their lives reflected in texts, further supports the possibilities of life histories. She asserts that life histories can change the way readers look at the world by offering new perspectives and promoting appreciation for those different than self. These new understandings then give rise to critical inquiry and illuminate the human experience.

Life Histories offer ways to enrich not only reading, but also writing, dramatic speaking, and use of digital tools in amplifying ideas. Literacy practitioners know that writing is not one thing and reading another. Rather, there exists a relationship between textual form and reading practice which has evolved over time and informs contemporary cultural discourse.

Life histories value collaboration - in both understanding the nuances of the selected character and in creating the written scripts for the final performance. Roberts and Wibbens (2010) argue that collaborative writing demonstrates measurable success over students' work not involved in collaborative writing.

Crafting life histories supports engagement with multicultural and/or critical texts. Life histories serve as a tool to help teachers support their students in a multi-layered analysis of provocative text. Life histories foster aesthetic experience and artistic expression through performance. Furthermore, we argue that life histories have the power to generate student excitement for literary engagement and to create a space where students come together joined in a common purpose. 


\section{References}

Bakhtin, M. (1986 [1979]). From notes made on 1970-71. In Mikhail Bakhtin, Speech genres and other late essays (transl. by V. McGhee, ed. by C. Emerson \& M. Holquist, pp. 132-158).

University of Texas Press.

Bruffee, K. (1999). Collaborative learning: Higher education, interdependence, and the authority of knowledge. Johns-Hopkins University.

Bruner, J. S. (1990). Culture and human development: A new look. Human Development, 33, 344-355.

Cole, A., \& Knowles, G. (2001). Lives in context: The art of life history research. AltaMira Press.

Edmiston, B., \& Wilhelm, J. (1998). Imaging to learn: Inquiry, ethics, and interaction through drama. Heinemann.

Flake, S. (1998). The skin I'm in. Jump at the Sun/Hyperion Books.

Linde, C. (1993) Life stories: The creation of coherence. Oxford University Press.

Nieto, S. (1992). Affirming diversity: The sociopolitical context of multicultural education.

Allyn \& Bacon Publishers.

Peacock, J., \& Holland, D. (1993). The narrated self: Life stories in process. Ethos, 21(4), 367-383.

Roberts, K., \& Wibbens, E. (2010). Writing first: Preparing the teachers of our youngest writers. In Putting writing research into practice: Applications for teacher professional development (pp. 179-205). The Guilford Press.

Rosenblatt, L. (1986). The aesthetic transaction. Journal of Aesthetic Education, 20, 122-128.

Rossiter, M. (1999). A narrative approach to development: Implications for adult education. Adult Education Quarterly, 50, 56-71.

Sikes, P. (2006). Auto-biographies and life histories. Retrieved from

https://www.scribd.com/document/313111656/Auto-Biographies-and-Life-Histories-Sikes-2006 


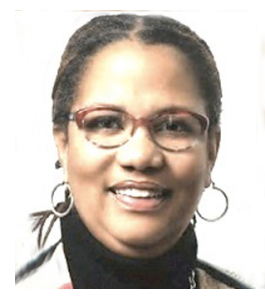

Susan Browne, Ed.D., is an Associate Professor in the Department of Language, Literacy and Sociocultural Education at Rowan University. Dr. Browne teaches undergraduate and graduate reading courses. She serves as a research advisor to Master's and Ed.D. candidates and teaches in the College of Education Center for Access, Equity and Success (CASE) Ph.D. Program. Dr. Browne's research interests and publications are in the areas of critical pedagogy, urban education, multicultural literature, and reader response.

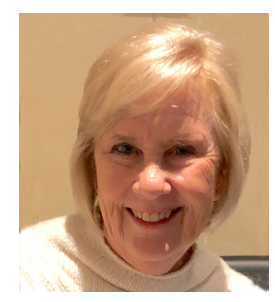

Marjorie Madden brings over 35 years to the teaching of reading, writing, and literacy. Dr. Madden currently teaches clinical courses at Rowan University in the undergraduate reading program and graduate courses in the Reading Specialist and Reading Practitioner tracks in the MA in Reading program. In addition to teaching, Dr. Madden codeveloped The Literacy Consortium, now in its 14 th year, which provides teacher-centered literacy symposiums across the year to 12 school districts.

As a researcher, Dr. Madden has published four books for Scholastic, most recently a new book focusing on reading and writing instruction in the new standards era. 